\title{
Computing English: The converging metaphors
}

\section{Jacques Coulardeau}

\section{OpenEdition}

\section{Journals}

Electronic version

URL: http://journals.openedition.org/asp/3723

DOI: 10.4000/asp.3723

ISSN: 2108-6354

\section{Publisher}

Groupe d'étude et de recherche en anglais de spécialité

\section{Printed version}

Date of publication: 1 December 1995

Number of pages: 41-56

ISSN: 1246-8185

Electronic reference

Jacques Coulardeau, « Computing English: The converging metaphors», ASp [Online], 7-10 | 1995,

Online since 30 July 2013, connection on 30 April 2019. URL : http://journals.openedition.org/ asp/3723 ; DOI : 10.4000/asp.3723

This text was automatically generated on 30 April 2019.

Tous droits réservés 


\title{
Computing English: The converging metaphors
}

\author{
Jacques Coulardeau
}

1 Anyone who has had a lot of contact with computing English knows the language is deeply metaphorical. Computing writers use all possibilities offered by the English language and aim at making it expressive, funny, subtle, at times hilarious, always attractive.

2 We all know the GUIs who sound so gooey that you get stuck to them like some fly to sticking tape. And this is only one example among many others, where the funny element is retained instead of the sterner.

3 Computing technicians, engineers and users are strange people who look for fun in their juggling with language. We also know the word "dongle" used for a hardware key and evoking something that dangles freely and that somewhere has some connection with the slang word "dong" for "penis".

4 However, my purpose here is not to look at those isolated metaphors. I am interested in the use of metaphors in a quite broader sense. I would like to look at the Gateway ads that are inserted in a magazine like Byte. Those ads spread over four to twelve or even more pages. They have a very complex structure and language.

5 First I will study the metaphorical scope of these ads over a period of two years. Second I will try to contrast one of the earlier ads and its use of metaphors with a very recent one and what metaphors have become in it. Third I will try to identify the aim of such ads and the public they are written for. That will bring me to a conclusion with another metaphor, that of Thornton A. May who compares an information technologist to Richard III. This should bring us to a close with some remarks on the difficulty such language represents in the teaching of that type of English to many computing students. I have studied ten different ads covering the period mid-1993 to the end of 1994. 


\section{Ten ads}

\section{1. "If I Only Had A Gateway!"}

6 This contains three metaphors, referring to three well-known characters who did something wrong because they did not have the computing power of a Gateway.

Bonanno Pisano, an engineer who built the leaning tower of Pisa in 1174. The mistake in the architecture is compared to the perfect Pentium Architecture of the Gateway 2000. There is a first metaphor involving Italy and Italians with exclamations like "Capice?", “ magnifico!", “mama mia!”, but also typical Italian culinary elements. The second metaphor is architectural: "skyscraper prices", "monumental performance", "a value that towers over the competition", "foundation-shaking power", "colossal power and performance", "solid foundation of performance and value".

Douglas Corrigan, who tried to fly from New York to California in 1938 and ended up in Ireland. This inadequate journey is metaphorically compared to the perfect traveling tools that the Hand Book and the Color Book constitute. The metaphor is richly relayed with such words as: "the transamerican flight", "wordly expedition", "steered me the right way", "transcontinental or transatlantic", "at the controls, steers you in the right direction and sends you flying", "high-in-the-sky performance", "supersonic performance", "leave the ground", "your eyes are not deceiving you", "it blows the competition out of the water", "you're headed in the right direction", "top-flight performance", "you'll soar", "you'll be in awe", "take flight", "taking the world by storm", "still up in the air", "head this way", "found on any continent", "a world traveler or an urban commuter", "go the 'wrong way"”.

Julius Caesar who was assassinated in the Roman Senate by his friends in 44 BC. This unhappy event is compared to the fantastic planning and pleasure you can get in life with a Gateway 2000 and its marvellous software. The metaphorical relay is less impressive: "who to trust", "competitive PC arena", "allies, supporting villages and empires alike", "loyal customers", "resting on these laurels", "support representatives to troubleshoot", "a lifetime", "legendary figures make speeches".

\section{2. "Saloon 2 1/2"}

This is a remake of another ad, Saloon, that I do not possess.

11 The idea is that if you play poker in a saloon you must have a good deal, a good hand, a winning hand, a royal flush. This situation is compared with the royal flush that Gateway puts down on the table for its customers. The 10 is the Hand Book and the Color Book. The Jack is the 4SX-33. The Queen is the Family PC. The King is the P5-60. The Ace is the P5-90. Add to that basic metaphor a secondary one: the Family PC is a frontier PC and Gateway is in North Sioux City, South Dakota, the wild midwest of old, and the old western frontier metaphor is thus developed.

Linguistically it is also rich: "hold on to your hat, pardner", "raisin' the stakes again", "when you bet on Gateway you're the winner with a hand that is unbeatable", "if you've been hangin' around the PC saloon for long", "a sequel to one that ran way back in the summer 1990", "taking our 'cue' from Hollywood, if 'Saloon' was a good ad, we might as 
well do 'Saloon $21 / 2$ '", "lookin' back... how many things have stayed the same", "the players around the industry poker table", "the game", "a royal flush of value", "oldfashioned, good service", "a small maverick company from the South Dakota frontier", "Yesirree, when you have a hankerin' just holler", "the best deal".

\section{3. "All He Does Anymore Is Tie Me Up In The Backyard"}

We are in a dog psychiatrist's office. This metaphor is very complex and told from the dog's point of view. The dog is a golden retriever. First he describes his lot with his master who is hooked to a Gateway 2000. Then he describes his lot with his mistress who is in the same way hooked to a Gateway Pentium PC. He even tries to become chef to the lady, who is not moved. Here the metaphor becomes ironical, funny. The menu he serves his mistress is fantastic and "she does not bat an eye": "Belgian endive salad, savory herbed croissants, wild rice pilaf, grilled apricot-ginger chicken breasts, and white chocolate cheesecake with luscious strawberry glaze. I threw in a bottle of chilled champagne and a few of my favorite doggy treats."

Then he discovers the Family PC with the kids, a boy and a girl of course, which is a common image of the family. And there he finds out that he can also get hooked to a PC and then he goes back into the family. He becomes a member of it again.

This first section of the ad has a sequel a hundred pages further down in this issue of Byte. This sequel starts with the leash the dog was presenting his master to beg for a walk. It is now broken. The dog is no longer a golden retriever but a basset; he has unleashed the power and is flying in the Gateway world.

So this metaphor works essentially on the level of who the narrator is and that of the visual elements.

\section{4. "Go Ahead Get Carried Away"}

This time we start with a hurricane and an imagination that goes wild. But when we open the trick box of the ad, we find a midwestern farm that has gone wild with Gateway. Here appears an important element. Gateway is in North Sioux City in South Dakota, in the heartland of America, with Deadwood, the center of a gold rush, Calamity Jane, the western frontier, but also corn, beans and cows. This state is particularly dear to my own personal heart since there is also a small village called Roubaix and a fishing lake going by the name of Roubaix Lake. Many of the Gateway metaphors are motivated by that location.

The farm gone wild is crammed with visual metaphors: a Gateway kite, Gateway cow boxes with black and white spots used as swings by the kids, flying Hand Books, a flying Color Book with a nest and eggs on the screen, amplifiers in the barn tower, a PC tower turned into a silo, a windmill as a camera zoom. Kids are flying on CDs and CDs are blooming in the flower beds. Even a CD-ROM drive is integrated in the barn wall.

And this visual metaphor goes on over four more pages added to the first seven. And it is relayed in the language. "Getting Carried Away" is going to be echoed by words like: "imagination", "go wild", "lose yourself", "whirlwind", "extraordinary", "fantastic", "legendary low prices", "a visionary's leap into", "supernatural”, "mesmerizing", "stunning", "all the stuff dreams are made of", "dreammachine", "your Shangri-La", "a 
sweet deal", "is it fantasy for real?", “awe-inspiring", "staggering", "heart-pounding", "know no boundaries", "you can have it all".

At times the same words can be found in different ads and they take different metaphorical values due to the context.

\section{5. “Don't Open Until 1994”}

A beautiful present box opens onto a party for "a party animal" which is a sheep, and then the party goes "hog-wild" with pigs. And then you "party on" with horses and you "crow" about Gateway with hens and chickens. And the "whole herd" of Gateway, 2,000 people, is pictured across two pages with the cow that is the symbol of the firm. Actually, in this ad the language is metaphorically poor and the metaphor is essentially visual.

\section{6. "The Choice Is No Longer Black And White"}

It introduces the Color Book. The metaphor is that of black and white cows in a pasture with a Color Book showing a colorful cow with blue, purple, red, yellow and green spots, the five colors that were already on the front page of the ad. The metaphor is linguistically exploited but not very much: "they've been milking the market", "a stampede in the industry", "greener pastures", "the grass is greener on the Color Book side of the fence".

This ad has a second part: "In Life Only A Few Things Inspire Passionate Loyalty". The metaphor is that of "passionate loyalty" and it refers to a Harley Davidson fan that has one of man's best friends as a friend and a Hand Book 486. It is the reference to a culture: that of a man's world with "Hawgs and Dogs". But once again it is not exploited very much on the linguistic level.

\section{7. "Behold"}

The next one is based on a religious metaphor and this time it is extensive and rich, both visually and linguistically. It starts with a monk looking up to the sky for inspiration, writing with a quill. The title is "Behold".

When you open the ad, the monk has discovered the "Good Books", to know the Hand Book and the Color Book. A stained glass window shows the $\mathrm{G}$ logo of Gateway in its upper half and a black and white cow in its lower half. The religious metaphor runs widely: "simply divine", "your next pilgrimage", "the answer to your prayers", "the genesis of", "is blessed", "Hand Book convert".

If you open that double page again into a triple page, the metaphor goes on with a chalice, white with red grapes and a loaf of bread. The Hand Book shows a letter to "Dear Friar Joe", though the Color Book is less directly linked to the metaphor with its "pages per day" graph. The text uses the metaphor extensively: "sing the praises", "in this world or the next", "the same chapter and verse", "out-of-this-world graphics", "your calling", "these 'Good Books", "a match made in heaven", "eternally grateful”.

This religious metaphor is somewhat typically American, even if it rings a rather Catholic bell. 


\section{8. "Gateway Just Went Platinum...”}

It is a metaphor with music from the very start with a platinum $\mathrm{CD}$ and the magic figure of 1,000,000 Personal Computers.

When you open the first double page you go on with the metaphor linguistically with the picture of a country singer on the screen of the computer that has of course a CD-ROM drive.

This double page opens into a triple page that is just entitled "Country". The image is that of a country barn with a banjo, boots, cowboy hats, a harmonica, saddlebags, an oil lamp and a basket of eggs. The text is divided into sections each having a title in the form of a country song title: "Those Old Time Country Values by The Low Overheads", "Gimme the Good Stuff by Hammer and the Boys", "Baby, Let Me Baby You by The Support Group". The country metaphor is developed in the text with a heavy reference to South Dakota, corn and bean fields, KSUX country radio, the Super Pig.

When we shift to the second double page, we shift to "Rock \& Roll", the Rock \& Rollers appearing in the shape of some monumental statues carved in the mountain side like in the shrine of Democracy, South Dakota. The black and white spot design appears on the electric guitar and on a guitar pick. This time the subtitles are Rock \& Roll song titles: "We Got the Goods by The Systematics", "Megahertz so Good by Pup and the Cells", "So you Wanta Fly by The Screamin' Vs", "Big Bandwidth Boogie by the Gates", "Workin' Up Some New Riffs by The Harmonics". The metaphor is richly and widely used in the text.

The third and last double page is entitled "All That Jazz" and the reference is to Jazz of course. With the car of a jazz band moving to a concert, a sight of a jazz club with table for two, piano, music parts, drums, and with a saxophone and a clarinet. In the same way as before the subtitles are jazz pieces: "Windows to the Other Side by Tommy Gee", "Software Improv by Good Vibes", "New Sensations by The Cool Tools", "Moovin' Up by The Upgrade Express", "Connectivity by The Local Area Group", "Wow by Talking Pictures in Motion".

3 Even the final page of the listing of products and features is set on a background of a guitar, thus closing the metaphor.

\section{9. "Power To The People"}

This is a back-to-the-60s ad and metaphor. It is a fourteen-page ad that starts with a group of Peace and Love Children in front of a black and white Gateway box and against a mural with a blazing sun and flowers. The reference is to Woodstock and the metaphor runs deep in the language.

Then we move to a double page dedicated to Armstrong walking on the moon but with a black and white Gateway flag - a reference to the space age.

Then we have a family picture, father, mother, son and daughter. The daughter is a trend setter and she amuses the other members of the family, but that is what happens when you buy a Gateway 2000, and then everyone imitates you.

7 In the following double page we move to the rolling stone that you are with your VW van all painted up with flowers, Love, Peace, Power To The People and peace signs. The 
reference runs through Esay Rider and psychedelic, revolutionary, radical, antiestablishment thinking.

It ends with a scene of dancers dancing the twist and of the Beatles on a screen. And it is suggested you add a twist to your Gateway PCI .

\subsection{0. "Twas The Night Before I Bought My PC"}

The last ad is a Christmas carol in verse that an elderly man tells about some dream he had when he tried to choose a PC. A Santa Cow, that works like an echo to the interjection "Holy Cow" that is yet never used, came up and introduced the man to Gateway.

The metaphor is that of Christmas, long and wide, ending up with Santa Cow eating cookies and drinking milk in the kitchen.

41 Every single element goes that way, even the cuckoo clock that has a black and white Santa Cow instead of a bird, or the happy moment of calling Gateway on a black and white spotted telephone.

This panorama, which is far from being complete and full, shows how rich this metaphorical field is.

\section{A contrastive approach}

The first type we may want to distinguish, the "bad" type, is best represented by the Present Box and the Party. It only, or nearly only, works on the visual level. The titles refer to the visual metaphor, but are the only linguistic elements going that way: "You Party Animal", "To Go Hog Wild", "Party On With", "To Crow About", "The Whole Herd".

But the text is only a commercial text in the third person: the vendor speaking to the consumer and telling him all the good things he knows about the products. It is a very ordinary ad at that level. discourses.

First, with each character, Bonanno Pisano, Douglas Carrigon and Julius Caesar, a story is told by the character, in the first person in a humorous at times sarcastic tone, though this tone sounds more like distanciation coming from the ad-master.

Each time the picture goes along with the story: the leaning tower of Pisa, a map of the US seen from ahigh and Julius Caesar from a film about him.

The metaphor is carried on in the presentation with the first text leaning like the tower of Pisa, the second text upside down like the pilot or the plane, and the third in Roman lettering.

On the computer, each time we have a metaphorical element: the Tower, the golden pot of a rainbow and the Coliseum.

We also have a brand metaphor with the black and white spot sign appearing on the front page (cups).

51 But the commercial text is purely commercial: in the third person from the vendor to the consumer. It is thus composed each time of different juxtaposed elements. 

style that has developed in American literature over the last twenty years thanks to the success of Stephen King in the literary field: the importance of a clear and characteristic location, the storytelling style itself, and the presence of symbolic elements in the material. I am not saying that the ad-masters are conscious of this connection, but the Stephen King style of literature has a pervading impact on American society, on its tastes and on its culture. This Applied Literature takes us far away from the simple, direct and at times brutal ads of the 50s and the 60s, and even probably of the 70s. We are living in the time of that new monstrous, popular and extremely enjoyable literature, best represented by Stephen King and Anne Rice, but also by Peter Straub and Clive Barker. We will note, though, that there is a connection in the storytelling style, but not in the genre which rarely touches on horror or the fantastique. It is at most some kind of soft fantasy. We must also think of TV advertising which is very creative though in a quite shorter proportion.

\section{The public}

Those ads aim at a particular public, or even maybe at particular publics. The general idea is that they try to cope with the public from the cultural point of view. They openly aim at the generation of people who have known the 60s: Woodstock, hippies, Rock and Roll, the Twist, Flower people, etc.

They also aim at different musical tastes: Rock and Roll, Country and Jazz, but not at classical music. Why not? Not at other arts like drama, painting, though a little at the cinema, especially with multimedia elements in those ads. The question of course is why or why not again? 
The ads have a strong leaning towards animals: farm animals, which look midwestern; and dogs. The position of the cow is special since it has become one of the emblems of the firm.

Apart from this cultural element that pervades those ads, it is necessary to see that there is a strong use of the intelligence and sense of humour of the public. The promoters of such ads obviously consider that the public must be flattered and entertained in its own culture. The public is considered as able to understand allusions, innuendo, humor. Finally the public is considered as literate and able to read and appreciate a story.

That is deeply different from all other ads in the computing field, but not entirely unique.

\section{Shakespeare and Richard III}

63 Shakespeare is the major reference in the field of English culture. We would think at first that the Brad is too literary, too cultural a reference to be quoted in a computing magazine like Byte. This explains my surprise when I came across the leading article "Shakespearean Wisdom" by Thornton A. May in the January 1994 issue (Thornton 1994).

4 The second surprise came with the character chosen as a metaphorical reference, Richard III. This character is, by far, the most famous king in shakespeare's plays. He is an infamous king, who has killed to become king and then becomes frigidly afraid of his own power and ends up selling his kingdom for a horse in order to escape his fate.

65 May compares the information technologist, or MIS (Management Information System) Director to Richard III.

What are the common elements?

To play Richard requires almost supernatural strength, skill, and endurance. An information technologist is also asked to play a bigger-than-life role in his or her organization.

Like Richard, many technologists have turned their uniqueness into a source of power. The technologist plays a crucial role in the increasingly important 'knowledge space' where money and technology combine to create business value. In Richard III, the action revolves almost totally around the title character. In a similar fashion, the decisions to acquire or implement technology revolve around the technologist. The technologist, as the central actor operating in the knowledge space, is responsible for identifying, verifying, and specifying how technology budgets will be allocated.

Hence May's conclusion: "Richard and contemporary technologists share many behavior traits."

Yet he puts forwards a few differences. The metaphor is also contrastive.

For one thing, Richard is a great actor. Technologists tend to be less theatrical in nature, less able to make protean shifts in behavior at a moment's notice.

They also tend to be truthful and fact-based - nothing is further from the truth for Richard.

Another dissimilarity is that Richard is malevolent. Information technologists, for the most part, are not.

If they have a flaw, it is that they are too self-effacing and too honest to play the political games that constitute such a lamentably large part of today's employment picture.

A key dissimilarity is that Richard is monodimensional. He has one and only one focus: he wants to be king. When he achieves that objective, he loses momentum 
and initiative. He fears the future." "The contemporary technologist does not stop just with identifying or specifying a technology to buy. The technologist not only looks forward to the future but also plays an active role in shaping that future.

Richard manages to alienate all those around him. Quite conversely, successful technologists draw people to them - not so much by the power of personality as by the power of thinking.

This illustrates well the theme of convergence and divergence.

Computing English makes very numerous cultural or referential elements converge into this field of knowledge marked by a high level of intelligence. It does so essentially through metaphors, comparisons and similes.

But computing writers seem to look for differences as much as common points. They make their metaphors, comparisons and similes diverge from the common points.

Gateway uses metaphors to attract some public, to widen the field of reference of their commercial procedures. Yet they build on the contrast the metaphors create, trying to surprise the reader, elaborate a certain level of disbelief, playing on humour and irony. If a dog understands the use of a Gateway computer, why shouldn't a man understand it too?

73 May very cleverly draws a parallel between Richard III and the technologist. This is the converging part. Then he opposes them too, and that is the diverging part. This requires intelligence on the side of the public and not only technical competence.

7 We must wonder if the mind of a technologist in the field of computing does not work like that. Is it not creative because it can both bring together and set apart, make things converge and diverge at the same time or successively?

5 I believe that that kind of language and discourse is only possible in this "knowledge space". In other fields they go straight to the point and do not beat about any bush. In other words computing technologists have a culture and a cultural mind and seem to use them on an everyday basis.

Computing English is a constant dilemma for the didactician. It is obvious the student needs to acquire an extremely vast linguistic knowledge in the very field of computing.

Jacques Hildebert's 1992 Dictionnaire de l'Anglais de l'Informatique contains 24,000 expressions and 3,000 acronyms and abbreviations. And this dictionary is not complete and every year several thousands of new items come into the picture. Alan Freedman's 1991 The Computer Glossary contained 4,300 words. George McDaniel's 1993 IBM Dictionary of Computing contains 18,000 entries.

Yet a student who knew computing English perfectly would be at a loss in many cases, because of the metaphors and references that delve into all sorts of other referential or cultural fields. How can our students who have so little literary or general English culture deal with these elements?

The answer is simple. They do not. And they apparently miss a lot. This is often the source of mistakes, misunderstanding, erroneous reactions.

With computing English, more than in any other brand of ESP, we are dealing with culture, general culture, as well as technical or scientific culture. The only other field that seems to be that widely open is audiovisual communication, but here, because of the message carried by the medium, not the medium itself. 


\section{BIBLIOGRAPHY}

Freedman, A. 1991. The Computer Glossary. Point Pleasant, PA: Amacom.

Hildebert, J. 1992. Dictionnaire de l'anglais de l'informatique. Paris: Presses Pocket.

McDaniel, G. 1993. IBM Dictionary of Computing. New York: McGraw-Hill.

May, T. A. 1995. “Shakespearean wisdom”. Byte 19/1, 312.

Thornton A. May. 1994. "Commentary: Shakespearean Wisdom: Richard III and information technologists have much in common, but there are differences". Byte Magazine 19/1, 312.

\section{APPENDIXES}

This example of my corpus shows the best form Applied Literature can take. We see the tale told from the dog's point of view -the picture, i.e., the dog's "dream" or "thought" or "tale" addressed to the dog's psychiatrist, and the symbols that are present in the page: the brand name with the G-logo, the slogan, and three instances of the black-andwhite spot pattern, with the mug on the lady's desk, the record sleeves next to the lady's desk, and the mousemat next to the computer in the left-hand bottom corner. It is obvious that such an ad, and this one runs over ten pages, is quite original in our field of reference.

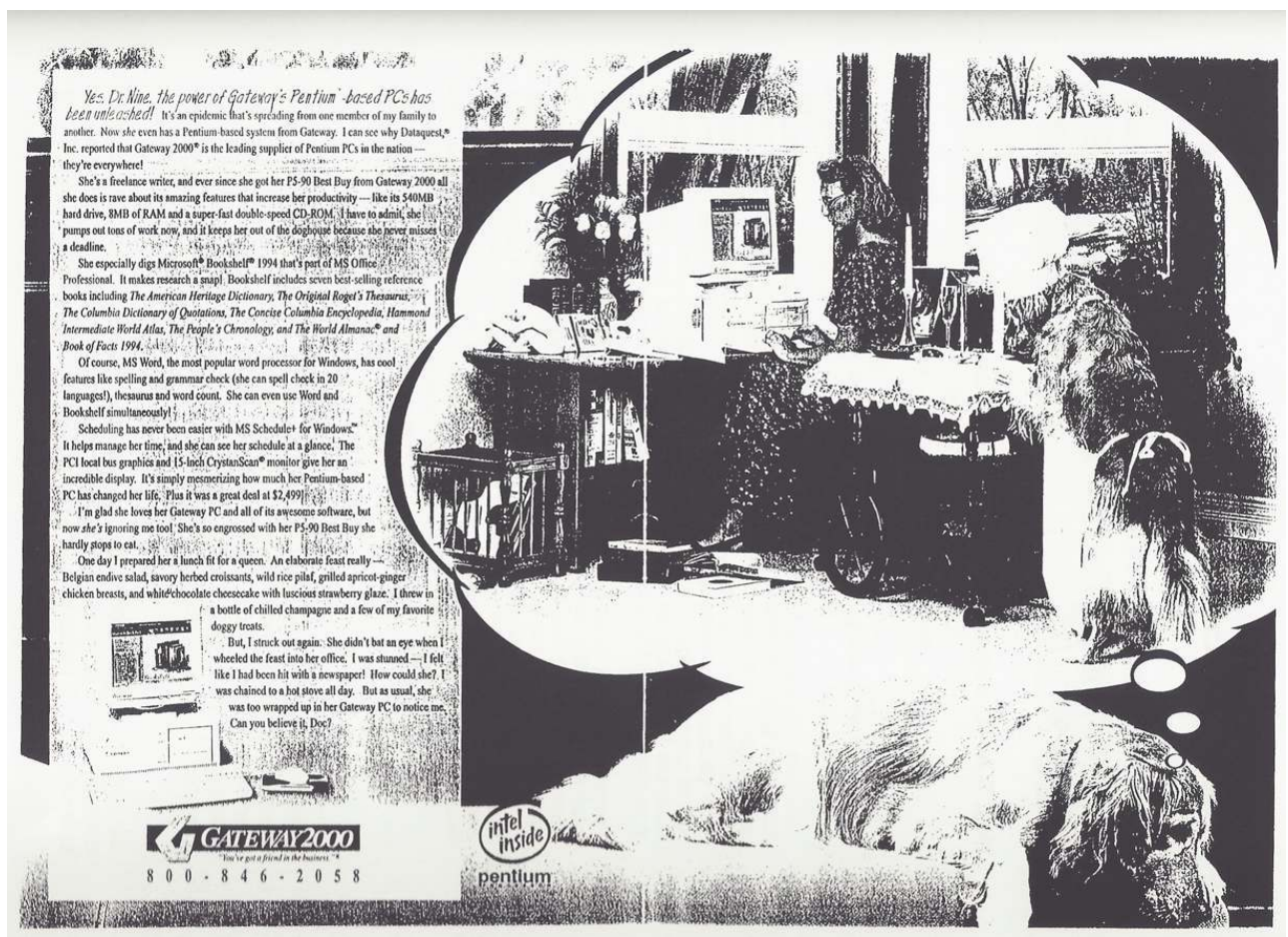




\section{ABSTRACTS}

In the very extensive ads of Gateway, an American computer brand name, we can find a style and a form that go widely beyond tradition and habit. We only have converging and diverging metaphors that crisscross with one another at the visual level as well as in the page lay out and the text. This is applied literature, like an echo of the popular literature that Stephen King or others write, calling upon the intelligence, the sense of humour and the story telling taste of present day American audiences.

Dans les publicités très extensives de Gateway, une marque d'ordinateur américaine, nous trouvons un style et une forme qui dépassent la tradition et l'habitude. Ce ne sont que métaphores convergentes et divergentes qui s'entrecroisent tant au niveau visuel qu'au niveau de la mise en page et du texte. On atteint le niveau de la littérature appliquée qui est comme un écho de la littérature populaire de Stephen King ou d'autres et qui fait appel à l'intelligence, au sens de l'humour et au goût du récit du public américain actuel.

\section{INDEX}

Keywords: advertising, applied literature, computer, metaphor

Mots-clés: littérature appliquée, métaphore, ordinateur, publicité

\section{AUTHOR}

\section{JACQUES COULARDEAU}

Jacques Coulardeau teaches at Lycée Jean Rostand, Roubaix, and at Université Lille 3.

dondaine@orange.fr 